\title{
Indian summer monsoon forcing on the deglacial polar cold reversals
}

\author{
Virupaxa K Banakar ${ }^{1,2, *}$, Sweta Baidya ${ }^{1,2}$, Alexander M Piotrowski ${ }^{3}$ \\ and D SHANKAR ${ }^{1}$ \\ ${ }^{1}$ CSIR-National Institute of Oceanography, Dona Paula, Goa 403004, India. \\ ${ }^{2}$ Academy of Scientific and Innovative Research (AcSIR), CSIR-NIO, Goa, India. \\ ${ }^{3}$ Department of Earth Sciences, University of Cambridge, Cambridge CB2 3EQ, UK. \\ *Corresponding author.e-mail: virupaxa56@gmail.com
}

Received: 5 December 2016 / Revised: 17 March 2017 / Accepted: 24 March 2017 /

Published online: 1 September 2017

The deglacial transition from the last glacial maximum at $\sim 20$ kiloyears before present (ka) to the Holocene (11.7 ka to Present) was interrupted by millennial-scale cold reversals, viz., Antarctic Cold Reversal ( 14.5-12.8 ka) and Greenland Younger Dryas ( 12.8-11.8 ka) which had different timings and extent of cooling in each hemisphere. The cause of this synchronously initiated, but different hemispheric cooling during these cold reversals (Antarctic Cold Reversal $\sim 3^{\circ} \mathrm{C}$ and Younger Dryas $\sim 10^{\circ} \mathrm{C}$ ) is elusive because $\mathrm{CO}_{2}$, the fundamental forcing for deglaciation, and Atlantic meridional overturning circulation, the driver of antiphased bipolar climate response, both fail to explain this asymmetry. We use centennialresolution records of the local surface water $\delta^{18} \mathrm{O}$ of the Eastern Arabian Sea, which constitutes a proxy for the precipitation associated with the Indian Summer Monsoon, and other tropical precipitation records to deduce the role of tropical forcing in the polar cold reversals. We hypothesize a mechanism for tropical forcing, via the Indian Summer Monsoons, of the polar cold reversals by migration of the Inter-Tropical Convergence Zone and the associated cross-equatorial heat transport.

Keywords. Paleoclimate; polar cold reversals; ITCZ; Indian monsoon; Arabian Sea; sediment core.

\section{Introduction}

Palaeo records show that during the last deglaciation, polar regions warmed and cooled asymmetrically, with more gradual and less extreme changes in the south (Blunier and Brook 2001; Shakun et al. 2012). The initial deglacial warming of $\sim 6^{\circ} \mathrm{C}(\sim 18-14.5 \mathrm{ka})$ in Antarctica was gradual (Parrenin et al. 2007), but the Greenland warmed rapidly by $\sim 11^{\circ} \mathrm{C}\left(\approx 7^{\circ} \%\right.$ increase of $\left.\delta^{18} \mathrm{O}_{\mathrm{ICE}}\right)$ during Bølling (15-14.4 ka) (Johnsen et al. 1992; Jouzel et al. 1995). During the following $\sim 0.5 \mathrm{ky}$, the Antarctic cooled by $\sim 3^{\circ} \mathrm{C}$, but this cooling paused for $\sim 1.5 \mathrm{ky}$ to form the Antarctic Cold Reversal (ACR: 14.5-12.8 ka). The ACR overlapped the $\sim 5^{\circ} \mathrm{C}$ cooling $(\sim 3 \%$ decrease of $\left.\delta^{18} \mathrm{O}_{\mathrm{ICE}}\right)$ during post-B $\varnothing$ lling that formed the Allerød ( 14.5-12.8 ka); subsequently, Greenland cooled by a further $\sim 5^{\circ} \mathrm{C}$ to form the coldest Younger Dryas (YD: 12.8-11.8 ka). Thus, the Ållerød and YD together form the Greenland cold reversal $(14.5-11.8 \mathrm{ka})$, similar to the ACR in Antarctic. Considering the polar temperatures at the end of last glacial maximum (LGM) as reference temperatures for the respective hemispheres, the subsequent deglacial bipolar 
thermal contrasts are distinctly different during cold reversals.

The role of $\mathrm{CO}_{2}$ in causing these deglacial cold reversals can be ruled out because a corresponding depletion in its atmospheric concentration did not occur during these cold reversals; instead, $\mathrm{CO}_{2}$ concentration remained constant at $\sim 240$ ppmv (Monnin et al. 2001). An anti-phased interhemispheric ocean-heat-budget is a necessity for the operation of Atlantic Meridional Overturning Circulation (AMOC: Crowley 1992; Wunsch 2006; Clement and Peterson 2008; Barker et al. 2009). Therefore, the AMOC is an unlikely driver of observed polar cold reversals because the cooling is synchronous in both Antarctic and Greenland ice-core records during ACR-Ållerød. Further, the YD fingerprint is not observed in subtropical sea surface temperature (SST) time series of the southern hemisphere (Calvo et al. 2007).

Tropical climate has generally been considered to respond to the rapid changes in Greenland, with the AMOC providing the teleconnection (Hong et al. 2003; Deplazes et al. 2013; Kesserkar et al. 2013; Marzin et al. 2013; Mohtadi et al. 2014), but dry and windy events in tropical East Africa preceding the Greenland stadials argue against this teleconnection (Brown et al. 2007). Such discrepancies with the AMOC hypothesis have led researchers to consider the tropics also as a possible forcing (Cane 1998; Koutavas et al. 2002; Wunsch 2006). However, formal mechanisms to link tropical forcing on extratropical climate change in the past are still in the formative stage (Chiang 2009). In this paper, we present a mechanism that links changes in the tropics (specifically the monsoon regime) to synchronous but differential cooling during the polar cold reversals. This mechanism invokes the migration of the Inter-Tropical Covergence Zone (ITCZ) and associated changes in monsoon precipitation, which together form a major cross-equatorial heat engine, and can be tested by reconstructing the sequence of deglacial changes in the tropics relative to the poles.

The seasonal latitudinal migration of the ITCZ is limited to $\sim 7^{\circ}$ over most of the Pacific except the western Pacific warm pool and the Atlantic (Philander et al. 1996; Schneider et al. 2014). The latitudinal displacement of the Pacific and Atlantic mean ITCZ position in the past is also limited to $\sim 0.6^{\circ}$ (McGee et al. 2014). In contrast, the ITCZ position swings by $\sim 28^{\circ}$ seasonally over the Indian Ocean and over the western Pacific warm pool (figure 1), which is warmer and transfers this heat to the atmosphere (Waliser and Jiang 2014). The ITCZ extends farther into the northern hemisphere (to the foothills of the Himalayas) than elsewhere owing to the south Asian summer monsoons (Gadgil 2003). The monsoon is associated with latent-heat release in the mid-troposphere and this heat is transported southward across the equator via the descending limb of the southern arm of the Hadley Cell (Heaviside and Czaja 2013). Studies show that the moisture-laden, low-level Somali Jet (Findlater 1969) that feeds the Indian Summer Monsoon (ISM) contributes more thermal energy to the cross-equatorial heat budget than do the Pacific and Atlantic ITCZs (Heaviside and Czaja 2013).

At present, the net global cross-equatorial atmospheric heat transport associated with the Hadley Cell is estimated to be $\sim 0.4$ PW into the southern hemisphere (Schneider et al. 2014), of which $>50 \%$ is associated with the ISM (Heaviside and Czaja 2013). Although recent modeling results of the past ITCZ based on tropical SST gradients limits the global mean displacement to $<1^{\circ}$ latitude (McGee et al. 2014), this result is heavily biased by the Pacific and Atlantic SSTs. Indeed, ISM rainfall is well correlated at present (Gadgil 2003) and in the past (Fleitmann et al. 2007) with the extent of northward migration of mean latitudinal position of the ITCZ.

The ITCZ always migrates towards the hemisphere that is warming more and its mean position is influenced by the inter-hemispheric temperature difference (Findlater 1969). This relationship has led to the monsoon being looked upon as responding to the Greenland climate (Wang et al. 2001; Hong et al. 2003; Sinha et al. 2005; Deplazes et al. 2013; Marzin et al. 2013), but we argue here that the cross-equatorial heat transport associated with it, a consequence of meridional asymmetry, makes the ISM a viable candidate mechanism for forcing extratropical climate, in particular the deglacial cold reversals. Successful chronological synchronization of various polar climate records (Pedro et al. 2011) has enhanced confidence in relating radiocarbon dated oceanic climate proxy records with those of polar ice-core records.

\section{Material and methods}

A $4.2 \mathrm{~m}$ long sediment core (ABP32-GC01R) was raised from the Eastern Arabian Sea (EAS) at $15^{\circ} 29.49^{\prime} \mathrm{N}$ latitude and $72^{\circ} 43.64^{\prime} \mathrm{E}$ longitude 


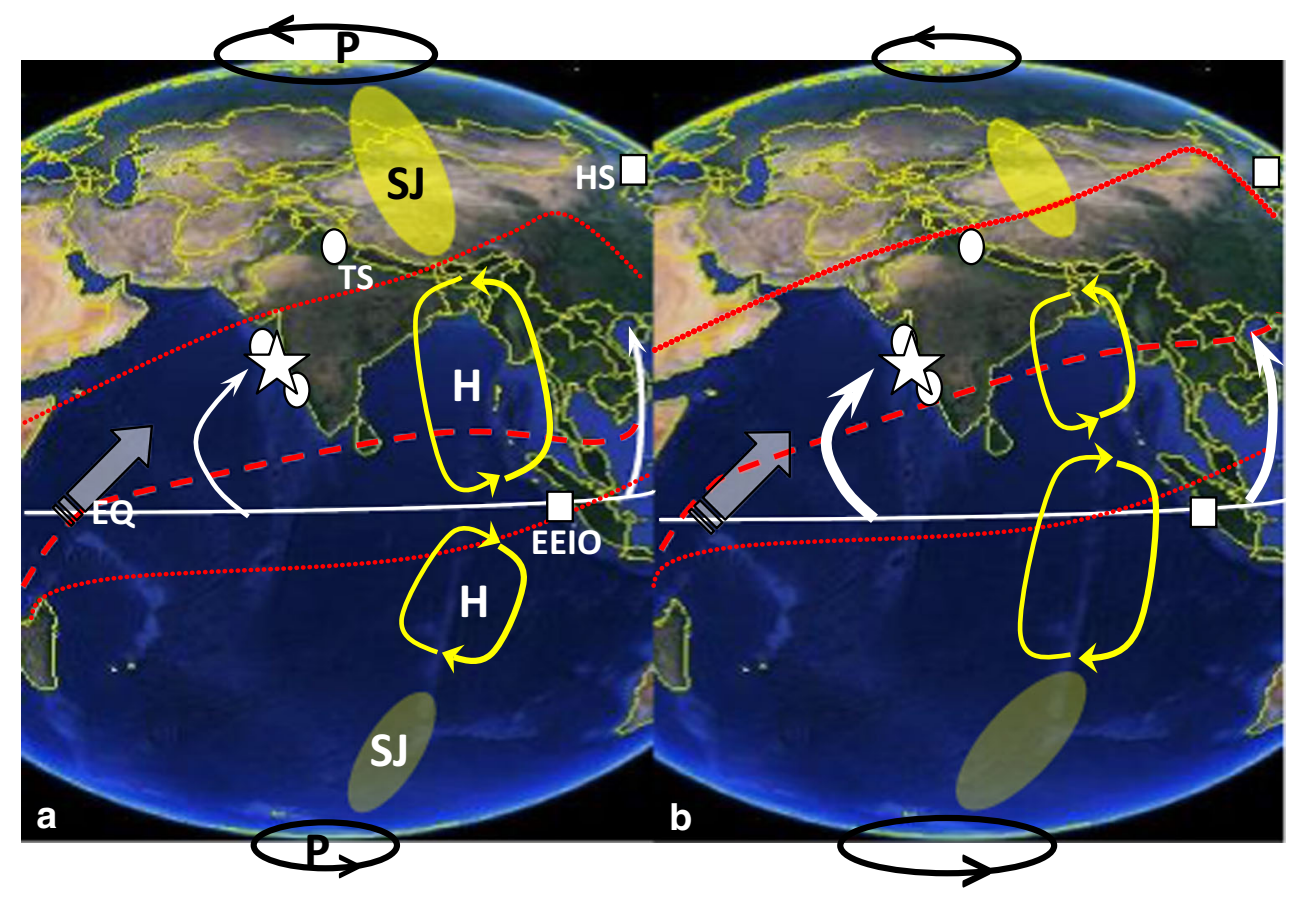

Figure 1. (a) Schematic drawing depicting present day atmospheric scenario and (b) likely scenario during the BøllingACR. Location of the present sediment core (ABP32-GC01R) from the EAS (white star) shown along with other tropical palaeomonsoon records presented in figure 3 [white squares: HS - Hulu Cave stalagmite, Northern China (Wang et al. 2001), and EEIO - Eastern Equatorial Indian Ocean sediment core SO189-39KL (Mohtadi et al. 2014) and those showing remarkably similar deglacial precipitation records but not shown in figure 3 (white circles), TS - Timta Cave stalagmite, western Himalaya (Sinha et al. 2005), and Southern-EAS (Kesserkar et al. 2013)]. The seasonal swing of ITCZ is shown with red dotted curved lines and its mean latitudinal position with broken red line (Gadgil 2003). In (b), the mean position of the ITCZ and its seasonal swing are arbitrarily shifted by $\sim 5^{\circ}$ northwards from the present scenario. Atmospheric circulation (labeled curved arrows) responsible for interhemispheric heat distribution are labeled in panel (a) $[\mathrm{H}=$ Tropical Hadley Cell - upward arrows indicate rising warm-flank of the cell and downward arrows are sinking-cold flank; SJ = Subtropical Jets-Large scale eddies; P = Polar eddies, adopted from Marshall and Plumb (2008)]. Somali Jet, a major contributor of static moisture to the Indian summer monsoons (Heaviside and Czaja 2013) is shown with grey-shaded block-arrow and summer monsoon flow is shown with curved white arrows wherein the thickness of arrows indicate arbitrary relative strength during two climate scenarios, (a) and (b). EQ = Equator. The background map is adopted from www.google.com/earth (US Dept. of State Geographer (c)2016 Google) under their universal fair-use license.

from a water depth of $642 \mathrm{~m}$ (figure 1). The sediment core was sliced in to $2 \mathrm{~cm}$ subsections. The mixed planktonic foraminifera from six depth sections were subjected to radiocarbon dating at the Arizona University's AMS Facility, USA. In the upper $56 \mathrm{~cm}$ of the sediment core, the abundance of planktonic foraminifera were not adequate for radiocarbon dating and the sections below 386 $\mathrm{cm}$ are not dated. The calculated sedimentation rates between two adjacent radiocarbon dated sections were used to develop the chronology for the sediment core (table 1 and figure 2). The ages below $386 \mathrm{~cm}$ depth are extrapolated considering linear sedimentation rate as obtained for succeeding dated section $(341-385 \mathrm{~cm})$. Total time-span covered by the core is 18 to $4.5 \mathrm{ky} \mathrm{BP}$. The reservoir age $\left(622 \mathrm{y}\right.$ at $16.50^{\circ} \mathrm{N}$ and $73.93^{\circ} \mathrm{E}$ in the EAS: Southan et al. 2002) corrected ${ }^{14} \mathrm{C}$ ages were calibrated to calendar ages (reference year: 1950 AD) using Quickcal2007 Ver.1.5 (Danzeglocke et al. 2009) (table 1).

The $\mathrm{Mg} / \mathrm{Ca}$ measurement was carried out at $2 \mathrm{~cm}$ interval subsections (time resolution $\sim 30$ 150 years), whereas, every second section was used for $\delta^{18} \mathrm{O}$ measurements (time resolution $\sim 60-300$ years). The upper mixed layer dwelling planktonic foraminifera $G$. sacculifer (without terminal sac) that is resistant to dissolution (Farmer et al. 2007) were handpicked from 250-355 $\mu \mathrm{m}$ coarse fractions, crushed between two glass plates. The fragments were homogenized with a fine brush and the visible clay lumps and oxide coated fragments were removed physically under microscope. Part of the aliquots were sent for $\delta^{18} \mathrm{O}$ measurement at the Godwin Laboratory, Cambridge University, UK, and remaining part was subjected to cleaning 
Table 1. Details of radiocarbon ages with associated errors.

\begin{tabular}{lcrr}
\hline $\begin{array}{l}\text { Interval } \\
(\mathrm{cm})\end{array}$ & Lab ref. no. & $\begin{array}{c}{ }^{14} \mathrm{C} \text { age } \\
(\text { years BP })\end{array}$ & $\begin{array}{c}{ }^{*} \text { Calendar age } \\
(\text { years BP })\end{array}$ \\
\hline $58-60$ & AA94193 & $4665 \pm 41$ & $4528 \pm 68$ \\
$124-126$ & AA94194 & $9665 \pm 52$ & $10216 \pm 25$ \\
$200-202$ & AA94195 & $10481 \pm 55$ & $11280 \pm 48$ \\
$256-258$ & AA94196 & $11283 \pm 59$ & $12659 \pm 67$ \\
$340-342$ & AA94197 & $13055 \pm 65$ & $14683 \pm 331$ \\
$384-386$ & AA94198 & $14262 \pm 72$ & $16723 \pm 264$
\end{tabular}

* Based on the reservoir age corrected (622 y: Southan et al. 2002). Reference year is $1950 \mathrm{AD}$.

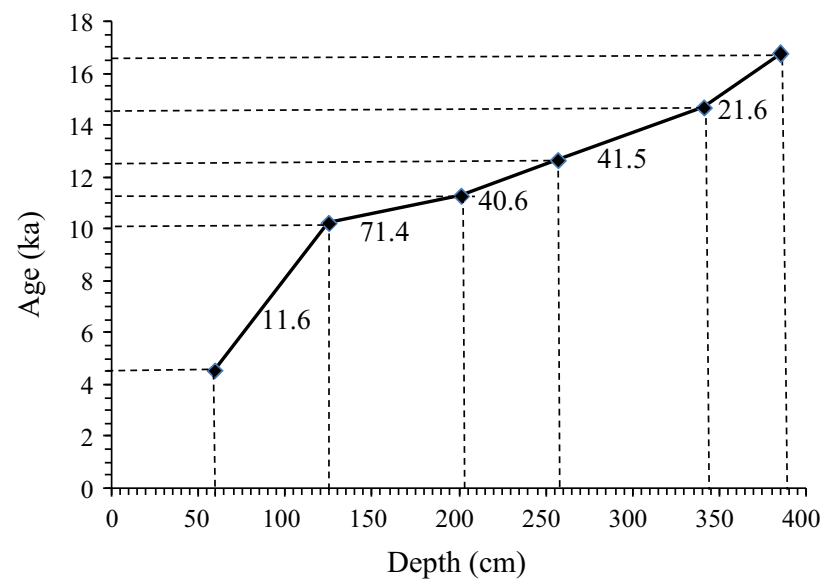

Figure 2. Depth vs. age model derived from five radiocarbon dated intervals (see table 1). The calculated sedimentation rate $(\mathrm{cm} / \mathrm{ky})$ is shown for each sediment segment between two adjacent dated sections. The broken vertical and horizontal lines are the radiocarbon dated sections' depth $(\mathrm{cm})$ in the sediment core and their corresponding ages (ka).

protocol following Barker et al. (2003), that constitutes successive removal of clay, organic coating and secondary calcite-crust followed by dissolution in $0.075 \mathrm{M}$ ultrapure $\mathrm{HNO}_{3}$.

The solutions were centrifuged at $14,000 \mathrm{rpm}$ for $10 \mathrm{~min}$ to eliminate any remaining sub-clay size particulates. The $\mathrm{Mg} / \mathrm{Ca}(\mathrm{mmol} / \mathrm{mol}$ ) was measured on an in-house Perkin-Elmer OPTIMA 7300 DV Simultaneous ICP-OES following intensity ratio calibration technique (DeVilliers et al. 2002). Further, to monitor any residual contamination by clays and oxides the $\mathrm{Al}, \mathrm{Fe}$, and $\mathrm{Mn}$ were also measured. A quality control solution with $\mathrm{Mg} / \mathrm{Ca}=4.46 \mathrm{mmol} / \mathrm{mol}$ was run at an interval of every five samples to monitor the effect of instrumental drift on measured $\mathrm{Mg} / \mathrm{Ca}$ of samples and corrected following step-correction wherever required. The spectra of $\mathrm{Al}, \mathrm{Fe}$ and $\mathrm{Mn}$ obtained for sample solutions appear mostly like the spectra for blank solution and their ratio with $\mathrm{Ca}$ rarely exceeding $0.3 \mathrm{mmol} / \mathrm{mol}$. The $\mathrm{X}-\mathrm{Y}$ scatter plots of $\mathrm{Al} / \mathrm{Ca}, \mathrm{Fe} / \mathrm{Ca}$ and $\mathrm{Mn} / \mathrm{Ca}$ vs. $\mathrm{Mg} / \mathrm{Ca}$ exhibited no correlation. These data-quality observations suggest that the analyzed $\mathrm{Mg} / \mathrm{Ca}$ is free from contamination. The $\mathrm{Mg} / \mathrm{Ca}(\mathrm{mmol} / \mathrm{mol})$ measured in QC $(n=90)$ over the time of experiment is $4.46 \pm 0.09 \mathrm{mmol} / \mathrm{mol}$ and for $\delta^{18} \mathrm{O}$ the standard precision of measurement is $0.1 \%$.

The $\mathrm{Mg} / \mathrm{Ca}(\mathrm{mmol} / \mathrm{mol})$ of $G$. sacculifer was translated in to SST utilizing a species-specific calibration derived for the tropical Atlantic having modern annual average SST and surface salinity $\left(\sim 27.5^{\circ} \mathrm{C}\right.$ and $\left.35.8 \mathrm{psu}\right)$ (Dekens et al. 2002), which are closely comparable to the annual average SST and surface salinity at our core location ( $\sim 28^{\circ} \mathrm{C}$ and 35.6 psu: www.nodc.noaa.gov/

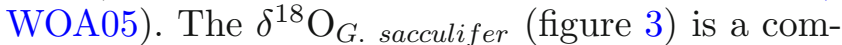
bined signal of temperature and $\delta^{18} \mathrm{O}_{\text {WATER }}$. The former represents the SST since the G. sacculifer lives in well-mixed upper surface layer of the ocean and the latter represents a mixture of global icevolume dependent whole ocean salinity and the local evaporation-precipitation (E-P) forced local surface salinity (SS). The global climate cooling (i.e., increased ice volume) results in increase of the $\delta^{18} \mathrm{O}_{\text {WATER }}$ up to $1.2 \%$ during the LGM (Shackleton 2000). Hence, the ice-volume corrected residual- $\delta^{18} \mathrm{O}_{\text {WATER }}$, a proxy for local salinity provides a powerful tool to reconstruct the changes in local precipitation. The $\delta^{18} \mathrm{O}_{\text {WATER }}$ is estimated from paleotemperature equation (Epstein et al. 1953) after correcting the $\delta^{18} \mathrm{O}_{G}$. sacculifer for global ice volume. This residual $\delta^{18} \mathrm{O}_{\text {WATER }}$ represents the salinity in the EAS, in turn ITCZISM associated precipitation. The surface salinity was estimated from $\delta^{18} \mathrm{O}_{\text {WATER-salinity rela- }}$ tionship in the Arabian Sea (Dahl and Oppo 2006). The calculated $1 \sigma$ standard errors (Schmidt 1999) for each of the time-series are presented in figure 3 . 


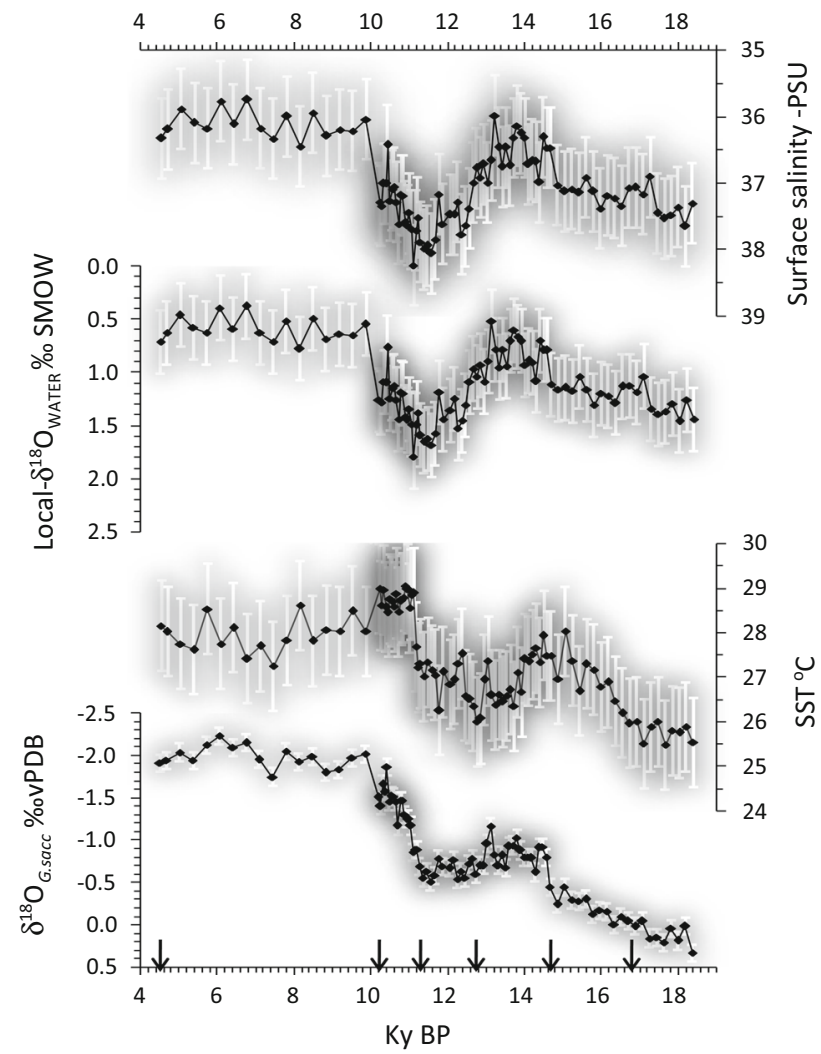

Figure 3. The time-series of $\delta^{18} \mathrm{O}$ of G. sacculifer, $\mathrm{Mg} / \mathrm{Ca}$ derived SST (Dekens et al. 2002), $\delta^{18} \mathrm{O}_{\text {WATER }}$ derived from Epstein et al. (1953) palaeotemperature equation and surface salinity derived from $\delta^{18} \mathrm{O}_{\text {WATER }}$ (Dahl and Oppo 2006) obtained from ABP32-GC01R. Capped vertical lines are $1 \sigma$ error bars and grey-shaded background is the propagation of error through the dataset (see Appendix). Downward arrows are the radiocarbon dated sections.

We have adopted the temperature interpretations of $\delta^{18} \mathrm{O}_{\mathrm{ICE}}$ in Greenland (Monnin et al. 2001; Stenni et al. 2001) and temperature anomalies of Antarctic (Johnsen et al. 1992; Monnin et al. 2001) for calculating relative changes in temperature. While discussing our results, we keep in mind (1) outside the upwelling cells of the Arabian Sea, a significant SST cooling occurs due to strong summer monsoon wind-forcing in parts of the Arabian Sea (Murtugudde et al. 2007), and (2) the lead-lags in the climate see-saw of the order of ocean mixing time have been found to be statistically indistinguishable (Steig and Alley 2002) and hence are not considered to be of significance here. As our present sediment core location is not known for intense upwelling such as off Oman and off Somalia, the SST changes therefore are mostly associated with ISM wind forcing. The $1 \sigma$ error on $\operatorname{SST}\left( \pm 0.96^{\circ} \mathrm{C}\right)$ and SS ( $\pm 0.6 \mathrm{psu})$ (Appendix) were calculated as the square-root of mean of the variance.

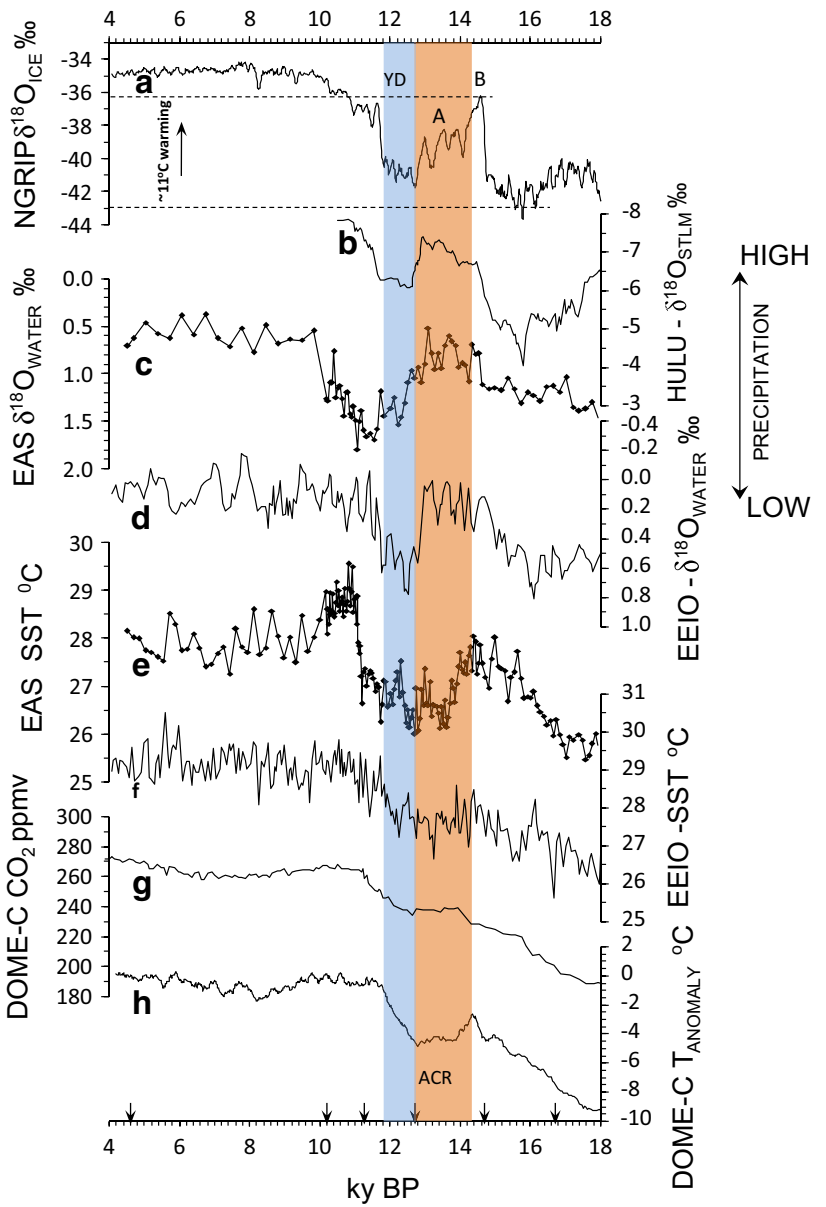

Figure 4. Deglacial evolution of polar and monsoonal regimes from the last glacial maximum to the present. The abscissa shows time in kiloyears before Present. Panels are arranged in order from north to south. (a) Greenland climate (Svensson et al. 2008) (5-point moving average); (b) Chinese monsoon precipitation (Wang et al. 2001); (c) Eastern Arabian Sea precipitation (our data); (d) Eastern Equatorial Indian Ocean precipitation (Mohtadi et al. 2014) (3-point moving average); (e) Eastern Arabian Sea SST (our data); (f) Eastern Equatorial Indian Ocean SST (Mohtadi et al. 2014); ( $\mathrm{g}$ ) Antarctic DOME-C CO $\mathrm{CO}_{2}$ record (Monnin et al. 2001); (h) Antarctic DOME-C temperature anomaly (Parrenin et al. 2007). Downward arrows indicate ages of radiocarbon dated sections of our sediment core from the Eastern Arabian Sea (c \& e). ACR: Antarctic Cold Reversal - orange shaded bar; B: Bølling; A: Ållerød; YD: Younger Dryas - blue shaded bar. $\sim 11^{\circ} \mathrm{C}$ warming at $\mathrm{B} \varnothing l$ ling (a) is obtained from temperature conversion of $\delta^{18} \mathrm{O}_{\mathrm{ICE}}$ (Johnsen et al. 1992; Jouzel et al. 1995).

\section{Results}

We present centennial-resolution time-series of paired $\mathrm{Mg} / \mathrm{Ca} \mathrm{SST}$ and local- $\delta^{18} \mathrm{O}_{\text {WATER }}$ (a proxy for local salinity controlled by evaporation minus precipitation ( $\mathrm{E}-\mathrm{P}$ or simply freshwater flux) extracted from a sediment core of the EAS and compared the deglacial hydroclimate of the EAS and other tropical sites (figure 4) with the polar 
Table 2. Deglacial polar climate and corresponding tropical monsoon climate variability with respect to the LGM climate scenario.

\begin{tabular}{|c|c|c|c|c|}
\hline Record (see figure 3) & Bølling & $\mathrm{ACR}^{\$}$ & YD & Ref. \\
\hline *Greenland temperature (a) & $+11^{\circ} \mathrm{C}\left(-15^{\circ} \mathrm{C}\right)$ & $+6^{\circ} \mathrm{C}\left(-20^{\circ} \mathrm{C}\right)$ & $+1^{\circ} \mathrm{C}\left(-25^{\circ} \mathrm{C}\right)$ & 1,2 \\
\hline Chinese rains: $\delta^{18} \mathrm{O}_{\text {stalagmite }}(\mathrm{b})$ & Strong: $\sim-0.5 \%$ & Strong: $\sim-6.5 \%$ & Weak: $\sim-6^{0} \%$ & 3 \\
\hline ISM rains- EAS: $\delta^{18} \mathrm{O}_{\text {seawater }}$ (c) & Strong: $\sim 0.7 \%$ & Strong: $\sim 0.6^{\circ} \%$ & Weak: $\sim 1.3 \%$ & $\#$ \\
\hline ITCZ rains- EEIO: $\delta^{18} \mathrm{O}_{\text {seawater }}(\mathrm{d})$ & Strong: $\sim 0.1 \%$ & Strong: $\sim 0.0 \%$ & Weak: $\sim 0.5 \%$ & 4 \\
\hline EAS SST (e) & $2{ }^{\circ} \mathrm{C}$ rise & $\cdots 1.5^{\circ} \mathrm{C}$ colder pause & $\cdots$ & $\#$ \\
\hline EEIO SST (f) & $2^{\circ} \mathrm{C}$ rise & $\cdots 0.5^{\circ} \mathrm{C}$ colder pause & $\cdots$ & 4 \\
\hline Antarctic $\mathrm{CO}_{2}(\mathrm{~g})$ & $\sim 50$ ppmv rise & $\cdots \sim 240$ ppmv pause & & 5 \\
\hline *Antarctic temperature (h) & $+6^{\circ} \mathrm{C}\left(-24^{\circ} \mathrm{C}\right)$ & $+3^{\circ} \mathrm{C}\left(-27^{\circ} \mathrm{C}\right)$ & $+7^{\circ} \mathrm{C}\left(-23^{\circ} \mathrm{C}\right)$ & 2 \\
\hline $\mathrm{N}-\mathrm{S}$ temperature gradient & $9^{\circ} \mathrm{C}$ & $7^{\circ} \mathrm{C}$ & $2^{\circ} \mathrm{C}$ & \\
\hline
\end{tabular}

* Temperature changes in the polar regions with reference to their respective temperatures at $\sim 18$ ka (LGM). Values in parenthesis are the actual temperatures expected during different climate events. At present (Holocene), observed annual average temperature north of Arctic Circle is $\sim-15^{\circ} \mathrm{C}$ (Karlsson and Svensson 2011) and at Little America, western Ross Sea of Antarctica is $\sim-23^{\circ} \mathrm{C}$ (Jones 1990), i.e., a modern temperature gradient of $\sim 8^{\circ} \mathrm{C}$. Back-tracking the temperatures to the end of LGM, based on temperature changes recorded in ice-cores (Jouzel et al. 1995), yield $\sim-26^{\circ} \mathrm{C}$ for Greenland and $\sim-30^{\circ} \mathrm{C}$ for Antarctica, i.e., a temperature gradient of $\sim 4^{\circ} \mathrm{C}$. These polar temperatures define the reference climate for 1) LGM to estimate past relative changes in respective polar temperatures, and 2) bipolar temperature set-up required to sustain the present position of the Indian Ocean ITCZ at $\sim 5^{\circ} \mathrm{N}$. Reduced temperature gradient at the LGM to $\sim 4^{\circ} \mathrm{C}$ as compared to modern $8^{\circ} \mathrm{C}$ might have caused southward displacement of the ITCZ, probably close to the Equator. Lowest temperature gradient at the YD might have resulted in the collapse of summer monsoons in the northern hemisphere as a result of extreme southward shift of the ITCZ. The letters in parentheses in the first column refer to the panels in figure 3. \#: Present study; 1: Johnsen et al. (1992), Jouzel et al. (1995); 2: Parrenin et al. (2007); 3: Wang et al. (2001); 4: Mohtadi et al. (2014); 5: Monnin et al. (2001)]. \$: The timing of ACR cold phase in Antarctica overlaps the timing of Ållerød cooling phase in Greenland.

climate records in three relevant time slices: Bølling ( 14.5 ka), ACR ( 14.5-12.8 ka), and YD ( 12.8$11.8 \mathrm{ka}$ ) (table 2). The EAS precipitation is representative of the ISM because higher precipitation in this region reflects stronger winds blowing across the Arabian Sea and over the Indian subcontinent to the Bay of Bengal (Gadgil 2003), and also it includes freshwater input from several seasonal Western Ghat (Deccan) mountain rivers.

Our data from the EAS show the two-step warming in the SST and decrease in $\delta^{18} \mathrm{O}_{\text {WATER }}$ seen in the polar deglaciation pattern (figure 4 ). The SST increases from $\sim 25.5^{\circ}$ to $\sim 28^{\circ} \mathrm{C}$ during pre-ACR, followed by a decrease of $\sim 2^{\circ} \mathrm{C}$ during $\mathrm{ACR}$, and remains cold $\left(\sim 26^{\circ} \mathrm{C}\right)$ through the YD (table 2). The $\delta^{18} \mathrm{O}_{\text {WATER }}$, on the other hand, decreases from $\sim 1.3 \%$ to $0.7 \%$ during pre-ACR, remains nearly constant $\sim 0.7 \%$ through the ACR, and increases to $\sim 1.5 \%$ during the YD. This freshwater input pattern is also seen in marine records from the Eastern Equatorial Indian Ocean (EEIO) (Mohtadi et al. 2014) and southeastern Arabian Sea (Kesserkar et al. 2013), and in terrestrial precipitation records from northern China (Wang et al. 2001) and western Himalaya (Sinha et al. 2005): all show strong precipitation at the warmest Bølling, which nearly overlaps the commencement of ACR (figure 4). Likewise, the SST variation in the EAS is consistent with timings of SST variability in the EEIO (Mohtadi et al. 2014).

\section{Discussion}

Several tropical marine and terrestrial palaeorecords have suggested southward displacement of ITCZ during LGM (Clement and Peterson 2008; Schneider et al. 2014), resulting in significant reduction of ISM precipitation (Banakar et al. 2010; Deplazes et al. 2013).

Considering the polar temperatures at the end of LGM ( $\sim 18 \mathrm{ka})$ as reference temperatures (see table 2 footnotes), the subsequent deglacial bipolar warming trends during the deglaciation are striking: at the $\mathrm{B} \varnothing$ lling the Greenland warmed $5^{\circ} \mathrm{C}$ more than the Antarctic, while during the ACR (that overlaps the Allerød-timing in Greenland), the Greenland was warmer by $5^{\circ} \mathrm{C}$ and the Antarctic was warmer by $\sim 3^{\circ} \mathrm{C}$ relative to their respective LGM temperatures. At the YD the Greenland was warmer only by $1^{\circ} \mathrm{C}$, whereas, in Antarctic the ACR not only terminated, but also warmed further by $\sim 4^{\circ} \mathrm{C}$ to yield a total rise of $\sim 7^{\circ} \mathrm{C}$ as compared to its LGM temperature (see table 2 and figure 4). A relatively more warmed Greenland with respect to its LGM temperature (by 
$5^{\circ} \mathrm{C}$ during the $\mathrm{B} \varnothing$ lling and $3^{\circ} \mathrm{C}$ during the $\mathrm{ACR}$ period: $\sim 14.5-12.8 \mathrm{ka}$ ) as compared to the Antarctic warming with respect to its LGM temperature, might have forced the Indian Ocean ITCZ to migrate northwards from its LGM's southerly position. This northward migration of the ITCZ might have intensified the cross-equatorial winds and the Somali Jet (Findlater 1969) leading to enhanced ISM precipitation in particular and tropical precipitation in general. Our data and the other records suggest that intensified tropical precipitation that coincided with the warm Bølling of Greenland continued through the ACR of the Antarctica (table 2 and figure 4).

From table 2, it is evident that the north-south polar temperature gradients (between Greenland and Antarctica) at different climate events varied significantly [i.e, at $\operatorname{LGM}(18 \mathrm{ka})=4^{\circ} \mathrm{C}$, YD $=$ $2^{\circ} \mathrm{C}, \mathrm{ACR}=7^{\circ} \mathrm{C}, \mathrm{B} \varnothing$ lling $=9^{\circ} \mathrm{C}$, and Holocene $($ modern $)=8^{\circ} \mathrm{C}$. When compared to the present day temperature gradient of $8^{\circ} \mathrm{C}$, that sets the modern location of the Indian Ocean mean ITCZ at $\sim 5^{\circ} \mathrm{N}$, the ITCZ at YD must have been most southward owing to significantly decreased bipolar temperature gradient and most northward at the Bølling owing to significantly increased gradient. This means that, the YD coincided with weakest ISM and the Bølling with strongest ISM, which are consistent with ISM intensity at different climatic events revealed by various sedimentary records (see table 2). Thus, cross-equatorial heat transport associated with ITCZ-ISM may have played a definite role in dictating relative warmth in polarregions.

When the ITCZ shifts north, it strengthens (weakens) the southern (northern) limb of the Hadley Cell because the ITCZ cannot shift poleward of the Himalayas, which act as a topographic barrier controlling the position of the northern hemisphere's subtropical jet stream (Ramaswamy 1956). Indeed, data from the Tropical Rainfall Measuring Mission (TRMM) show that intense precipitation occurs on the southern flanks of the Himalayas (Houze et al. 2007). When the southern limb of the Hadley Cell strengthens, more heat is exported to the southern hemisphere upper atmosphere, which is transmitted to the Antarctic by large-scale subtropical and polar eddies (Marshall and Plumb 2008). Hence, a connection between polar temperatures and the ISM intensity is feasible.

The cross-equatorial heat transport via the strengthened Hadley Cell and its transmission southward by the large-scale subtropical and polar eddies could be more effective and rapid than that transmitted via the warm returning arm of the AMOC. Hence, we hypothesize that a warming of the Greenland, could pull the ITCZ farther north over the Indian Ocean, which can reverse the Antarctic cooling via the intensified ISM. Therefore, following the $\mathrm{B} \varnothing$ lling, the Antarctic recorded only $\sim 3^{\circ} \mathrm{C}$ cooling during the ACR, whereas, corresponding Ållerød in the Greenland recorded a cooling of $\sim 5^{\circ} \mathrm{C}$ (figure 4), probably due to increased loss of heat to the southern hemisphere caused by intensified ISM. This interpretation is consistent with enhanced southern subtropical atmospheric circulation during the ACR (Stenni et al. 2001). Two lines of evidences can be provided in support of our hypothesis. The first line of evidence is an anti-correlation between the Antarctic sea-ice extent and the all India monsoon rainfall intensity on annual timescale in the modern time (19792000 dataset: Dugam and Kokade 2004). That is, an increased ISM rainfall warms the Antarctic region leading to decreased sea-ice extent and vice-versa. The second line of evidence is that the last three deglacial warmest events in Antarctic have been associated with synchronous weakening of the Asian monsoons on millennial timescales (Chen et al. 2016). That is, long-term warming of the Antarctic forces the Asian monsoons to weaken, apparently by pulling mean position of the ITCZ southward.

Our hypothesis implies that the excess thermal energy reaching the extratropics of the southern hemisphere during the ACR arrested the Antarctic cooling only to $\sim 3^{\circ} \mathrm{C}$ (Jouzel et al. 1995; Parrenin et al. 2007) and terminated it at $\sim 12.8$ ka. The corresponding reduction of thermal energy reaching northern hemisphere extratropics would have forced the Greenland to cool further through the Allerød resulting the YD, which is in antiphase with the ACR. With the onset of YD, the intense ITCZ-ISM precipitation, which was sustained since the Bølling and through the ACR-Allerød, would reach its nadir, as reflected in the decreased ISM over a vast tropical regime (figure 4). The accumulated thermal energy in the southern hemisphere throughout the ACR, evident in warming of the Southern Indian Ocean at that time (Stenni et al. 2001), might have rendered Antarctica to warm by $\sim 3^{\circ} \mathrm{C}$ when the YD conditions were prevalent in the Greenland. Relatively more warmed Antarctic during the YD appears to have reduced the bipolar temperature gradient to a minimum 
$\left(2^{\circ} \mathrm{C}\right.$ : table 2$)$ that has forced the mean ITCZ to migrate to its extreme southward position leading to significant weakening of the ISM. A significantly weakened ISM during the YD in turn might have reduced the cross-equatorial transport of northern hemisphere heat into the southern hemisphere causing restoration of warming in Greenland that terminated the YD.

\section{Conclusions}

In summary, we hypothesize that the differentially cooled cold reversals in polar climates during the last deglaciation appeared to have driven by meridional shifts in the ITCZ over the Indian Ocean and the associated changes in the ISM. It is unlikely that any single mechanism, whether $\mathrm{CO}_{2}, \mathrm{AMOC}$, or tropical forcing via the ISM, will suffice to explain all the events seen in the palaeoclimate records. It is more likely that the global climate system consists of several cause-effect relationships, all interacting to affect the observed changes in climate. This hypothesis of tropical forcing of polar cold reversals, via the ISM, fills a niche in the jigsaw puzzle that constitutes the complex global climate system. The proposed tropical-atmospheric hypothesis driving the deglacial global climate if validated by simulation experiments has a potential to contribute to the development of predictive models of global climate under anthropogenic forcing.

\section{Acknowledgements}

This work is the part of the GEOSINKS Program funded by the CSIR. DS thanks MoES for funding through their CTCZ program. The sediment core was collected with the assistance of crew on board $R V$ Boris Petrov chartered by the MoES for Cobalt-Crust Exploration program. SB thanks CSIR for her research fellowship. We thank Mike Hall and James Rolfe for oxygen isotope measurements at Godwin Laboratory, University of Cambridge, UK and DeMartino Mitzi of the Arizona University, USA for AMS-radiocarbon measurements. The constructive reviews by anonymous reviewers were of great help while revising the manuscript. This is NIO contribution No. 6024.

\section{Appendix}

Radiocarbon age (ka), $\delta^{18} \mathrm{O}_{G}$. sacculifer $(\% \mathrm{vPDB}), \mathrm{Mg} / \mathrm{Ca}(\mathrm{mmol} / \mathrm{mol})$, estimated $\mathrm{SST}\left({ }^{\circ} \mathrm{C}\right)$, estimated residual- $\delta^{18} \mathrm{O}_{\text {SEAWATER }}(\%$ vSMOW) and estimated surface salinity (psu) at the location of ABP32GC01R sediment core.

\begin{tabular}{|c|c|c|c|c|c|c|}
\hline $\begin{array}{l}\text { Depth } \\
(\mathrm{cm})\end{array}$ & $\begin{array}{l}\text { Age } \\
\text { (ka) }\end{array}$ & $\begin{array}{l}\delta^{18} \mathrm{O}_{\text {G. sacculifer }} \\
\% \text { o } \mathrm{PDB}\end{array}$ & $\begin{array}{c}\mathrm{Mg} / \mathrm{Ca} \\
(\mathrm{mmol} / \mathrm{mol})\end{array}$ & $\begin{array}{l}\text { SST } \\
\left({ }^{\circ} \mathrm{C}\right)\end{array}$ & $\begin{array}{l}\delta^{18} \mathrm{O}_{\text {SEAWATER }} \\
(\% \text { vSMOW })\end{array}$ & $\begin{array}{l}\text { Salinity } \\
\text { (PSU) }\end{array}$ \\
\hline 59 & 4.53 & -1.91 & 4.718 & 28.2 & 0.71 & 36.3 \\
\hline 61 & 4.70 & -1.94 & 4.668 & 28.0 & 0.63 & 36.2 \\
\hline 65 & 5.05 & -2.04 & 4.550 & 27.7 & 0.46 & 35.9 \\
\hline 69 & 5.39 & -1.94 & 4.454 & 27.6 & 0.58 & 36.1 \\
\hline 73 & 5.73 & -2.13 & 4.819 & 28.5 & 0.63 & 36.2 \\
\hline 77 & 6.08 & -2.23 & 4.543 & 27.7 & 0.39 & 35.8 \\
\hline 81 & 6.42 & -2.1 & 4.221 & 26.8 & 0.59 & 36.1 \\
\hline 85 & 6.77 & -2.15 & 4.477 & 27.4 & 0.38 & 35.8 \\
\hline 89 & 7.11 & -1.95 & 4.600 & 27.7 & 0.63 & 36.2 \\
\hline 93 & 7.46 & -1.75 & 4.410 & 27.3 & 0.72 & 36.3 \\
\hline 97 & 7.80 & -2.05 & 4.630 & 27.8 & 0.52 & 36.0 \\
\hline 101 & 8.15 & -1.93 & 4.465 & 28.6 & 0.78 & 36.5 \\
\hline 105 & 8.49 & -1.99 & 4.614 & 27.8 & 0.49 & 36.0 \\
\hline 109 & 8.84 & -1.8 & 4.719 & 28.1 & 0.69 & 36.3 \\
\hline 113 & 9.18 & -1.84 & 4.705 & 28.0 & 0.64 & 36.2 \\
\hline 117 & 9.53 & -1.97 & 4.901 & 28.5 & 0.65 & 36.2 \\
\hline 121 & 9.87 & -2.02 & 4.706 & 28.0 & 0.55 & 36.0 \\
\hline 125 & 10.22 & -1.51 & 5.127 & 29.0 & 1.26 & 37.3 \\
\hline 129 & 10.27 & -1.4 & 4.960 & 28.6 & 1.28 & 37.3 \\
\hline 133 & 10.33 & -1.66 & 5.115 & 29.0 & 1.09 & 37.0 \\
\hline
\end{tabular}


Appendix. (Continued.)

\begin{tabular}{|c|c|c|c|c|c|c|}
\hline $\begin{array}{l}\text { Depth } \\
(\mathrm{cm})\end{array}$ & $\begin{array}{l}\text { Age } \\
\text { (ka) }\end{array}$ & $\begin{array}{l}\delta^{18} \mathrm{O}_{G . \text { sacculifer }} \\
\% \text { v } \mathrm{PDB}\end{array}$ & $\begin{array}{c}\mathrm{Mg} / \mathrm{Ca} \\
(\mathrm{mmol} / \mathrm{mol})\end{array}$ & $\begin{array}{l}\mathrm{SST} \\
\left({ }^{\circ} \mathrm{C}\right)\end{array}$ & $\begin{array}{l}\delta^{18} \mathrm{O}_{\text {SEAWATER }} \\
(\% \text { vSMOW })\end{array}$ & $\begin{array}{l}\text { Salinity } \\
\text { (PSU) }\end{array}$ \\
\hline 137 & 10.38 & -1.57 & 4.940 & 28.6 & 1.10 & 37.0 \\
\hline 141 & 10.44 & -1.87 & 4.889 & 28.5 & 0.77 & 36.4 \\
\hline 145 & 10.50 & -1.45 & 5.024 & 28.8 & 1.25 & 37.3 \\
\hline 149 & 10.55 & -1.53 & 4.997 & 28.7 & 1.15 & 37.1 \\
\hline 153 & 10.61 & -1.52 & 4.942 & 28.6 & 1.13 & 37.1 \\
\hline 157 & 10.66 & -1.45 & 5.079 & 28.9 & 1.26 & 37.3 \\
\hline 161 & 10.72 & -1.17 & 4.892 & 28.5 & 1.44 & 37.6 \\
\hline 165 & 10.78 & -1.47 & 5.004 & 28.7 & 1.19 & 37.2 \\
\hline 169 & 10.83 & -1.47 & 5.032 & 28.8 & 1.20 & 37.2 \\
\hline 173 & 10.89 & -1.3 & 5.157 & 29.0 & 1.42 & 37.6 \\
\hline 177 & 10.94 & -1.25 & 5.122 & 29.0 & 1.45 & 37.6 \\
\hline 181 & 11.00 & -1.26 & 4.934 & 28.6 & 1.35 & 37.5 \\
\hline 185 & 11.06 & -1.17 & 5.066 & 28.8 & 1.49 & 37.7 \\
\hline 189 & 11.11 & -0.86 & 5.081 & 28.9 & 1.80 & 38.2 \\
\hline 193 & 11.17 & -0.89 & 4.564 & 27.7 & 1.50 & 37.7 \\
\hline 197 & 11.22 & -0.89 & 4.373 & 27.2 & 1.39 & 37.5 \\
\hline 201 & 11.28 & -0.69 & 4.410 & 27.3 & 1.60 & 37.9 \\
\hline 205 & 11.38 & -0.55 & 4.297 & 27.0 & 1.66 & 38.0 \\
\hline 209 & 11.48 & -0.63 & 4.421 & 27.3 & 1.62 & 37.9 \\
\hline 213 & 11.58 & -0.51 & 4.355 & 27.2 & 1.69 & 38.1 \\
\hline 217 & 11.67 & -0.58 & 4.312 & 27.1 & 1.58 & 37.9 \\
\hline 221 & 11.77 & -0.78 & 4.013 & 26.3 & 1.19 & 37.2 \\
\hline 225 & 11.87 & -0.69 & 4.336 & 27.1 & 1.44 & 37.6 \\
\hline 233 & 12.07 & -0.67 & 4.233 & 26.8 & 1.36 & 37.5 \\
\hline 237 & 12.17 & -0.77 & 4.270 & 26.9 & 1.25 & 37.5 \\
\hline 241 & 12.27 & -0.54 & 4.411 & 27.3 & 1.53 & 37.3 \\
\hline 245 & 12.36 & -0.63 & 4.497 & 27.5 & 1.46 & 37.8 \\
\hline 249 & 12.46 & -0.55 & 4.137 & 26.6 & 1.31 & 37.6 \\
\hline 253 & 12.56 & -0.72 & 4.108 & 26.5 & 1.09 & 37.4 \\
\hline 257 & 12.66 & -0.78 & 4.045 & 26.3 & 0.96 & 37.0 \\
\hline 261 & 12.76 & -0.6 & 3.925 & 26.0 & 1.04 & 36.8 \\
\hline 265 & 12.85 & -0.7 & 3.949 & 26.1 & 0.93 & 36.9 \\
\hline 269 & 12.95 & -0.7 & 4.269 & 26.9 & 1.09 & 36.7 \\
\hline 273 & 13.04 & -0.96 & 4.434 & 27.4 & 0.90 & 37.0 \\
\hline 277 & 13.14 & -1.16 & 4.138 & 26.6 & 0.52 & 36.7 \\
\hline 281 & 13.24 & -0.83 & 4.060 & 26.4 & 0.79 & 36.0 \\
\hline 285 & 13.33 & -0.7 & 4.142 & 26.6 & 0.95 & 36.5 \\
\hline 289 & 13.43 & -0.82 & 4.084 & 26.5 & 0.78 & 36.8 \\
\hline 293 & 13.53 & -0.68 & 4.134 & 26.6 & 0.94 & 36.5 \\
\hline 297 & 13.62 & -0.93 & 4.183 & 26.7 & 0.71 & 36.7 \\
\hline 301 & 13.72 & -0.94 & 4.048 & 26.4 & 0.60 & 36.3 \\
\hline 305 & 13.82 & -1.03 & 4.335 & 27.1 & 0.66 & 36.1 \\
\hline 309 & 13.91 & -0.88 & 4.167 & 26.7 & 0.71 & 36.3 \\
\hline 313 & 14.01 & -0.8 & 4.452 & 27.4 & 0.93 & 36.3 \\
\hline 317 & 14.10 & -0.8 & 4.428 & 27.4 & 0.89 & 36.7 \\
\hline 321 & 14.20 & -0.79 & 4.489 & 27.5 & 0.91 & 36.7 \\
\hline 325 & 14.30 & -0.62 & 4.550 & 27.7 & 1.08 & 36.7 \\
\hline 329 & 14.39 & -0.91 & 4.419 & 27.3 & 0.70 & 37.0 \\
\hline 333 & 14.49 & -0.92 & 4.666 & 27.9 & 0.79 & 36.3 \\
\hline 337 & 14.59 & -0.8 & 4.482 & 27.5 & 0.79 & 36.5 \\
\hline 341 & 14.68 & -0.45 & 4.480 & 27.5 & 1.11 & 36.5 \\
\hline 345 & 14.87 & -0.24 & 4.275 & 27.0 & 1.16 & 37.0 \\
\hline 349 & 15.05 & -0.45 & 4.704 & 28.0 & 1.15 & 37.1 \\
\hline 353 & 15.24 & -0.29 & 4.437 & 27.4 & 1.17 & 37.1 \\
\hline 357 & 15.42 & -0.28 & 4.171 & 26.7 & 1.04 & 37.1 \\
\hline 361 & 15.61 & -0.3 & 4.405 & 27.3 & 1.16 & 36.9 \\
\hline
\end{tabular}




\begin{tabular}{|c|c|c|c|c|c|c|}
\hline $\begin{array}{l}\text { Depth } \\
(\mathrm{cm})\end{array}$ & $\begin{array}{l}\text { Age } \\
\text { (ka) }\end{array}$ & $\begin{array}{l}\delta^{18} \mathrm{O}_{G . \text { sacculifer }} \\
\% \text { vPDB }\end{array}$ & $\begin{array}{c}\mathrm{Mg} / \mathrm{Ca} \\
(\mathrm{mmol} / \mathrm{mol})\end{array}$ & $\begin{array}{l}\mathrm{SST} \\
\left({ }^{\circ} \mathrm{C}\right)\end{array}$ & $\begin{array}{l}\delta^{18} \mathrm{O}_{\text {SEAWATER }} \\
(\% \text { vSMOW })\end{array}$ & $\begin{array}{l}\text { Salinity } \\
\text { (PSU) }\end{array}$ \\
\hline 365 & 15.80 & -0.13 & 4.357 & 27.2 & 1.31 & 37.1 \\
\hline 369 & 15.98 & -0.17 & 4.210 & 26.8 & 1.20 & 37.4 \\
\hline 373 & 16.17 & -0.16 & 4.247 & 26.9 & 1.22 & 37.2 \\
\hline 377 & 16.35 & 0.00 & 4.092 & 26.5 & 1.29 & 37.2 \\
\hline 381 & 16.54 & -0.09 & 3.992 & 26.2 & 1.13 & 37.3 \\
\hline 385 & 16.72 & -0.04 & 3.911 & 26.0 & 1.13 & 37.1 \\
\hline 389 & 16.91 & 0.02 & 3.921 & 26.0 & 1.19 & 37.1 \\
\hline 393 & 17.09 & -0.04 & 3.754 & 25.5 & 1.04 & 37.2 \\
\hline 397 & 17.28 & 0.16 & 3.881 & 25.9 & 1.35 & 36.9 \\
\hline 401 & 17.46 & 0.15 & 3.922 & 26.0 & 1.39 & 37.5 \\
\hline 405 & 17.65 & 0.21 & 3.742 & 25.5 & 1.37 & 37.5 \\
\hline 409 & 17.84 & 0.04 & 3.853 & 25.8 & 1.30 & 37.5 \\
\hline 413 & 18.02 & 0.19 & 3.838 & 25.8 & 1.46 & 37.4 \\
\hline 417 & 18.21 & 0.02 & 3.883 & 25.9 & 1.26 & 37.6 \\
\hline \multirow[t]{3}{*}{421} & 18.39 & 0.33 & 3.763 & 25.5 & 1.45 & 37.3 \\
\hline & & MEAN & 4.434 & 27.3 & 1.06 & 37.0 \\
\hline & & $1 \sigma$ error & & 0.96 & 0.34 & 0.60 \\
\hline
\end{tabular}

\section{References}

Banakar V K et al. 2010 Climatology of the Eastern Arabian Sea during the last glacial cycle reconstructed from paired measurements of foraminiferal $\delta^{18} \mathrm{O}$ and $\mathrm{Mg} / \mathrm{Ca}$; Quat. Res. 73 535-540.

Barker S et al. 2003 A study of cleaning procedures used for foraminiferal $\mathrm{Mg} / \mathrm{Ca}$ paleothermometry; Geochem. Geophys. Geosyst. 48407.

Barker S et al. 2009 Interhemispheric Atlantic seesaw response during the last deglaciation; Nature $4571097-$ 1102.

Blunier T and Brook EJ 2001 Timing of millennial-scale climate change in Antarctica and Greenland during the last glacial period; Science 291 109-112.

Brown E T et al. 2007 Abrupt change in tropical African climate linked to the bipolar seesaw over the past 55000 years; Geophys. Res. Lett. 34 L20702.

Calvo E et al. 2007 Antarctic deglacial pattern in a $30 \mathrm{kyr}$ record of sea surface temperature offshore south Australia; Geophys. Res. Lett. 34 L13707.

Cane M A 1998 A role for the tropical Pacific; Science 282 59-61.

Chen S et al. 2016 Strong coupling of Asian monsoon and Antarctic climates on sub-orbital timescales; Sci. Rep. $\mathbf{2}$ 32995, doi: 10.1038/srep32995.

Chiang J C H 2009 The tropics in paleoclimate; Ann. Rev. Earth Planet Sci. 37 263-297.

Clement A C and Peterson L C 2008 Mechanism of abrupt climate change of the last glacial period; Rev. Geophys. 46 RG4002.

Crowley T J 1992 North Atlantic deep-water cools the southern hemisphere; Paleoceanogr. 7 489-497.

Dahl A K and Oppo D W 2006 Sea surface temperature pattern reconstructions in the Arabian Sea; Paleoceanogr. 21 PA1014, doi: 10.1029/2005PA001162.

Danzeglocke U, Joris O and Weninger B 2009 CalPal$2007^{\text {ONLINE }}$; www.calpal-online.de.
Deplazes G et al. 2013 Links between tropical rainfall and north Atlantic climate during the last glacial period; Nature Geosci. 6 213-217.

Dekens P S et al. 2002 Core-top calibration of $\mathrm{Mg} / \mathrm{Ca}$ in tropical foraminifera: Refining paleotemperature estimation; Geochem. Gephys. Geosyst. 3 1022-1036.

DeVilliers S et al. 2002 An intensity ratio calibration method for accurate determination of $\mathrm{Mg} / \mathrm{Ca}$ and $\mathrm{Sr} / \mathrm{Ca}$ of marine carbonates by ICP-AES; Geochem. Geophys. Geosyst. 3 1001-1010.

Dugam K K and Kokade S B 2004 Antarctic sea-ice and monsoon variability; Indian J. Radio Space Phys. 33 306309.

Epstein S et al. 1953 Revised carbonate-water isotopic temperature scale; Bull. Geol. Soc. Am. 64 1315-1325.

Farmer E C et al. 2007 Corroborating ecological depth preferences of planktonic foraminifera in the tropical Atlantic with the stable isotope ratios of core-top specimen; Paleoceanogr. 22 PA3205.

Findlater J 1969 A major low level air current near the Indian Ocean during northern summer; Quart. J. Roy. Meteor. Soc. 95 362-380.

Fleitmann D et al. 2007 Holocene ITCZ and Indian monsoon dynamics recorded in stalagmites from Oman and Yemen; Quat. Sci. Rev. 26 170-188.

Gadgil S 2003 The Indian monsoon and its variability; Ann. Rev. Earth Planet. Sci. 31 429-467.

Heaviside C and Czaja A 2013 Deconstructing the Hadley Cell heat transport; Quart. J. Roy. Meteor. Soc. 139 2181-2189.

Hong Y T et al. 2003 Correlation between Indian Ocean summer monsoon and north Atlantic climate during the Holocene; Earth Planet. Sci. Lett. 211 371-380.

Houze Jr R A et al. 2007 Monsoon convection in the Himalayan region as seen by the TRMM precipitation radar; Quart. J. Roy. Meteor. Soc. 133 1389-1411.

Johnsen S J et al. 1992 Irregular glacial interstadials recorded in a new Greenland ice core; Nature 359 311-313. 
Jones PD 1990 Antarctic temperatures over the present century - a study of the early expedition record; J. Climate 3 1193-1203.

Jouzel J et al. 1995 The two step shape and timing of the last deglaciation in Antarctica; Clim. Dyn. 11 151-161.

Karlsson J and Svensson G 2011 The simulation of Arctic clouds and their influence on the winter surface temperature in present-day climate in the CMIP3 multi-model dataset; Clim. Dyn. 36 623-635.

Kesserkar P M et al. 2013 Variation in the Indian summer monsoon intensity during the Bølling-Ållerød and Holocene; Paleoceanogr. 28 413-425.

Koutavas A et al. 2002 El-Nino like pattern in ice age tropical Pacific sea surface temperatures; Sceince 297 226-230.

Marzin C et al. 2013 Glacial fluctuations of the Indian monsoon and their relationship with north Atlantic climate: New data and modeling experiments; Clim. Past. 9 21352151.

McGee D et al. 2014 Changes in ITCZ location and crossequatorial heat transport at the last glacial maximum, Heinrich Stadial-1 and the mid-Holocene; Earth Planet. Sci. Lett. 390 69-79.

Marshall J and Plumb RA 2008 The general circulation of the atmosphere; In: Atmosphere, ocean, and climate dynamics - an introductory text (eds) Dmowska R, Hrtmann D and Rossby H T, Inter. Geophys. Union, Ser. Monogr. 93319.

Mohtadi M et al. 2014 North Atlantic forcing of tropical Indian Ocean climate; Nature 509 76-80.

Monnin E et al. 2001 Atmospheric $\mathrm{CO}_{2}$ concentration over the last glacial termination; Science 291 112-114.

Murtugudde R et al. 2007 Arabian Sea response to monsoon variation; Paleoceanogr. 22 PA4217.

Parrenin F et al. 2007 The EDC3 chronology for the EPICA Dome-C ice core; Clim. Past. 3 485-497.

Pedro J B et al. 2011 The last deglaciation: timing the bipolar seesaw; Clim. Past. 7 671-673.
Philander S et al. 1996 Why the ITCZ is mostly north of the equator; J. Clim. 9 2958-2972.

Ramaswamy C 1956 On the sub-tropical jet stream and its role in the development of large scale convection; Tellus $826-59$.

Schmidt GA 1999 Error analysis of palaeosalinity calculations; Paleoceanogr. 14 422-429.

Schneider T et al. 2014 Migration and dynamics of the intertropical convergence zone; Nature 513 4553.

Shackleton N J 2000 The 100000 year ice-age cycle identified and found to lag temperature, carbon dioxide and orbital eccentricity, Science 289 1897-1902.

Shakun J D et al. 2012 Global warming preceded by increasing carbon-dioxide concentration during the deglaciation; Nature 484 49-54.

Sinha A et al. 2005 Variability of southwest Indian summer monsoon precipitation during the Bolling-Allerod; Geology 33 813-816.

Southan J et al. 2002 Marine reservoir correction for the Indian Ocean and southeast Asia; Radiocarbon 44167 180.

Steig E J and Alley R B 2002 Phase relationship between Antarctic and Greenland climate records; Ann. Glaciol. 35 451-456.

Stenni B et al. 2001 An oceanic cold reversal during the last deglaciation; Science 293 2074-2077.

Svensson A et al. 2008 A 60,000 y Greenland stratigraphic ice core chronology; Clim. Past 4 47-57.

Waliser D E and Jiang X 2014 Tropical meteorology: Intertropical convergence zone; Encycl. Atmos. Sci., 2nd edn, Elsevier, doi: 10.1016/B978-0-12-382225-3.00417-5.

Wang Y J et al. 2001 A high resolution absolute-dated late Pleistocene monsoon records from Hulu caves, China; Science 294 2345-2348.

Wunsch C 2006 Abrupt climate change: an alternative view; Quat. Res. 65 191-203. 